\title{
Numeral constructions in spoken Italian and Spanish: from quantitative approximation to interpersonal relationships
}

\author{
CONSTRUCCIONES NUMERALES EN ITALIANO Y ESPAÑOL HABLADO: DE LA \\ APROXIMACIÓN CUANTITATIVA A LAS RELACIONES INTERPERSONALES
}

\section{Miriam Voghera}

Università di Salerno

Resumen

Dos consideraciones generales pueden derivarse de todos los datos considerados. En primer lugar, es posible rastrear un continuo de NuCxs en función de su grado de cohesión, fijación, especificidad e idiomaticidad, que se correlaciona con el tipo de significado y función aproximada o vaga. Cuanto más se vuelven idiomáticos los NuCx, menos expresan cantidad. En muchos casos, las construcciones adquieren un valor pragmático y codifican una manera de expresar el grado de compromiso, la actitud de los hablantes y el tipo de relación que le gustaría entablar con el destinatario. En estos casos, los diversos niveles de vaguedad a menudo están muy entrelazados y no se desenredan fácilmente. En segundo lugar, las construcciones numéricas aproximadas con números pequeños parecen más específicas y fijas en comparación con aquellas con números grandes. Probablemente esto se deba a su frecuencia, ya que sabemos que los números pequeños se usan mucho más que los números grandes (Mehler y Dehaene 1992). Aunque es necesario investigar más sobre este punto específico, estos resultados parecen ser otro elemento que confirma que los medios para ser vagos son más numerosos que los que transmiten las funciones opuestas (Caffi 2007).

PALABRAS CLAVE: construcciones numerales, italiano hablado, español hablado
Abstract

Two general considerations can derived from all the considered data. Firstly, it is possible to trace a continuum of NuCxs based on their degree of cohesion, fixedness, specificity and idiomaticity, which correlates with the kind of approximate or vague meaning and function. The more the NuCxs become idiomatic the less they express quantity. In many cases, the constructions acquire a pragmatic value and codify a manner of express the degree of commitment, the attitude of the speakers and the kind of relationship s/he would like to enter into with the addressee. In these cases, the various levels of vagueness are often thickly intertwined and not easily untangled. Secondly, the approximate numeral constructions with small numerals seem more specified and fixed compared with those with large ones. Probably this is due to their frequency, since we know that small numerals are much more used than large numerals (Mehler\&Dehaene 1992). Although it is necessary to do further research on this specific point, these results seem to be another element confirming that the means to be vague are more numerous than those that convey the opposite functions (Caffi 2007).

KEY WORDS: numeral constructions, spoken Italian, spoken Spanish 


\section{The quantitative approximation}

Let us look at the following examples:

(1) See you in four minutes

(2) There are thirteen things to see in the city

These two sentences, although perfectly normal and understandable, would be acceptable only under specific conditions: the first, for example, if we were to take a train or a plane, the second, if we were to organize a tour for a group of tourists. In everyday conversation, however, they would sound inappropriate and would probably be replaced by two less precise, but more socially adequate sentences:

(3) See you in five/ten minutes.

(4) In the city there are hundreds/thousands things to see.

Since 1975, Crystal and Davy had noticed that in conversation it is common to use vague language, i.e. approximate and unspecific. This is not because speakers are lazy or inaccurate, but because under normal communication conditions it is sufficient to approximate both to be quicker and to avoid unnecessarily redundant information.

The label vague language has spread since the nineties, thanks to the title of the book by Johanna Channell (1994), specifically dedicated to the semantic and pragmatic processes used by speakers when they cannot or do not want to be precise, and was then used by various other authors (Jucker et al. 2003; Cutting ed. 2007). The vague language phenomena were studied under the notions of vagueness, mitigation, attenuation, indeterminacy, in different areas of linguistic sciences: philosophical and linguistic pragmatics (Caffi 2007; Machetti 2006; Mihatsch 2007; Bazzanella 2011a) and analysis of spoken language (Briz 1998, 2003; Albelda\&Mancera 2011; Ghezzi 2013; Voghera 2012, 2017a, 2017b, 2017c). Many works converged on some phenomena, which seem pervasive, and among these, the quantity approximation (Mihatsch 2010a, 2010b; Bazzanella 2011; Ghezzi 2013; Albelda 2014; Voghera 2017c). The ability to approximate quantity develops very early in humans (Dahaene 1997). Sixmonth-old children are already able to assess roughly the number of elements in a set, and this ability improves throughout their lives. If six-month-old children can distinguish two sets, one of which contains twice as many elements as the other, nine-month-old ones can discriminate between two sets, one of which contains a third more elements than the other. The ability to approximate is so refined in adults that they can distinguish sets that differ only in a measure of $7 / 8$ (Halberda, Ferguson 2008). The approximate system number (ASN) is an essential part of what constitutes the "number sense" and several studies show that the ability to approximate and its development are an integral part of the acquisition of the skills of formal calculation, which are acquired through the use of numbers (Dahaene 1997). Therefore, approximation and calculation are cognitively connected, even if the latter cannot take place before linguistic development, i.e. the acquisition of use of symbolic signs (Pica et al. 2004, Park\&Brannon 2013). Quantitative approximation, being an integral part of our cognitive abilities, is reflected obviously at the linguistic level in a high number of expressions explicitly dedicated to this purpose, according to the various contexts and needs (Channell 1994). 
As we know, even cardinal numerals can function as vague quantifiers (Channel 2004, Krifka 2007, Lavric 2010, Bazzanella 2011, Voghera 2017c)'.

(5) avrà detto due parole / a alta voce / in classe (s/he) will have said a few (lit. two) words aloud in class (C-ORAL ROM)

(6) esas editoriales / normalmente les dan más a los profesores / universitarios / que les pagan cuatro duros <por ello> /(C-ORAL ROM) 'those leading articles/normally are given to universitary professors whom are paid a little money (lit. four pounds)'

(7) è per questo che io / il rappresentante / lo rifarei / cento volte (C-ORAL ROM) 'that's why I/ the salesman I would do it again a hundred times'

(8) pero es que yo eso se lo he dicho cien mil veces / (C-ORAL ROM) 'but I told him that thousands of times (lit. one hundred thousand times)'

The numerals in the examples (5)-(8) do not designate the cardinal numbers 2, 4, 100 and 100,000 , but approximate quantities small and large. As signs of a natural-historical language they do not escape the systemic vagueness of the code and therefore can extend or narrow the boundaries of their meaning. In fact, they can designate also indefinite and approximate quantities, comparable to those ones of the paucal or multal quantifiers.

Although the uses of numerals up to ten are paraphrasable with some, a few and similar words and the uses of larger numerals with many, the approximate value is not attributable to the numerals themselves but depends on the co-text in which they are inserted. In fact, the vague meaning belongs to the constructions of which the numerals are part. A construction (C), according to Goldberg definition, is a formal ( $\mathrm{Fi}$ ) and semantic $(\mathrm{Si})$ pair "such that some aspect of $\mathrm{Fi}$ or some aspect of $\mathrm{Si}$ is not strictly predictable from C's component parts or from other previously established constructions" (Goldberg 1995, p. 4).

In this article I will present the most common numeral constructions in spoken Italian and Spanish for quantity approximation, based on the corpora of spoken Italian VoLIP (Voghera et al. 2014), spoken Spanish Val.ES.Co. (http://www.valesco.es/) and the Italian and Spanish sections of the C-ORAL-ROM (Cresti \& Moneglia (eds.) 2005). I have analysed the contexts with the presence of numerals from 1 to 10 , to which I will refer in the course of this work as small numerals, and the contexts with the presence of numerals $20,25,50,100,500,1000,50,000,100,000$, one million, one billion, to which I will refer as large numerals. I will take into consideration here the approximation that is achieved through the exclusive use of cardinal numerals and not the one in which the numerals occur together with other approximators, such as adverbs (circa, hacia, più $o$ meno, más o menos 'about, more or less' etc.), or colloquial large numbers, such as the Spanish veintetantos, tropecientos, tropecientos mil.

Section 2 presents a description of the lexical and syntactic properties of the constructions; section 3 analyses the functions of constructions, comparing in particular those with small numerals and those with large numerals.

\footnotetext{
1 The examples are not translated literally, but the literal translation of the numeral is reported when necessary.
} 


\section{The constructions}

Both in Italian and in Spanish it is possible to identify four types of constructions in which the cardinal numerals have a meaning of quantitative approximation. The constructions can be made with both small and large numerals, but, as we shall see, with different semantic and pragmatic effects.

\section{1. Constructions with numeral pairs}

Numeral pairs are the most studied constructions (CxNuPair)2 because they are those present in the greatest number of languages (Pollmann, Jansen 1996, Eriksson, Bailey, Geaky 2010). In fact, they exploit a syntactic and semantic model of a not solved explicit alternative between two numerical values:

el piso pues lo tenemos alquilado hace ya dos o tres meses // más de tres meses(C-ORAL ROM)

' we've been renting the apartment for the last couple of months (lit. two or three months) more than three months

ho suonato e dopo tre o quattro minuti si apre la porta (VoLIP)

'I rang and after three or four minutes the door opened'

As matter of fact, CxsNuPair do not express a real alternative between two numerical values, but indicate an interval between two quantities, whose boundaries are not rigid 3 . The numbers of the pair, rather than indicating the lower and upper limit of the interval, indicate that it is an approximation located at a certain point in the numerical series (Channel 1994).

This construction has some variants, which we can consider as alloconstructions (Masini 2016):

numeral $_{1}$ o numeral $2 \mathrm{~N}$ : due o tre cose, dos o tres meses

'two or three things', two or three months'

(12) numeral ${ }_{1}$ numeral $_{2} \mathrm{~N}$ : due tre cose, diez quince minutos 'two three things', 'ten fifteen minutes'

(13) numeral ${ }_{1} \mathrm{~N} \circ$ numeral 2 : due cose o tre

(14) numeral $_{1} \mathrm{~N}+$ numeral $_{2} \mathrm{~N}$ : 'two things or three'

ci starà due ore tre ore 's/he will stay there two hours three hours'

The most common form in both languages is that one in (11). It is interesting to note that in (12) the form adapts to the meaning because the deletion of the conjunction makes the distinction between the numerals opaque also on the formal level. By this way the expression of a unique approximate value is even more stressed:

(15) son dieci vent'anni

'it has been ten or twenty (lit. ten twenty) years'

(16) se trata de dejar en quince veinte segundos (C-ORAL ROM)

\footnotetext{
2 Following a common convention, I use $\mathrm{Cx}$ as abbreviation of Construction.

${ }^{3}$ Obviously, the same sentence can be realized as a proper disjunction with a different prosodic phrasing (Voghera 2017a; Voghera\&Borges 2017).
} 
The forms in (13) and (14) have a very low frequency and some of them are mainly in Italian.

All forms of construction can be preceded by the singular masculine indeterminate article un in Italian and by the plural masculine, unos, or feminine indeterminate article, unas, in Spanish. In this way, the construction becomes a real indefinite NP: this solution is much more used in Spanish than in Italian.

(17) unos veinte veinticinco kilómetros (C-ORAL ROM)

'about twenty twentyfive (lit. a.MAS.PLU twenty twentyfive) kilometers'

All numerals can be part of $\mathrm{CxCoNu}$ without limitation, as long as the first number is smaller than the second one ${ }^{4}$. The overwhelming majority of pairs are however made up of round numbers, which are numbers that have the property of giving as a result a number from 1 to 9 when they are divided by 10, 100, 1000 etc., by 2, 20, 200, 2000 etc. or by 5, 50, 500, 5000 (Pollmann, Jansen, 1996):

(18) creo que eran / veinticinco / o treinta (C-ORAL ROM)

'I think they were twentyfive or thirty

(19) porque tienes cincuenta> / o sesenta / operarios (C-ORAL ROM) 'because you have fifty or sixty workers'

In these cases, vagueness is expressed at two levels: with the use of the round number, which indicates an approximate quantity in itself, and with the $\mathrm{CxCoNu}$, which indicates an interval of values with indeterminate boundaries (Channell 1994).

\subsection{Constructions with numerals in series}

Numerals can be used not only in pairs, but also in series (CxNuSeries), where there is a progression from a smaller to a larger number (Mihatsch 2010b):

(20) grandes salas / de quince / veinte / y cuarenta enfermos / (C-ORAL ROM)

'big halls for fifteen twenty and forty sick people'

The CxNuSeries follow the model of composition of list constructions (LCs) which are mostly the junction of three elements occupying the same structural position in a dependency structure, expressed by different or partially different lexical material, as illustrated in the following example (Voghera 2018):

(21) butteranno giù qualcosa da \# insomma da riferire, su cui parlare, su cui [...] (VoLIP)

lavorare 'they will write down something to report on, to talk about,'

${ }^{4}$ It is possible to find some exceptions to this rule, cfr. Halberda, Ferguson 2008. 


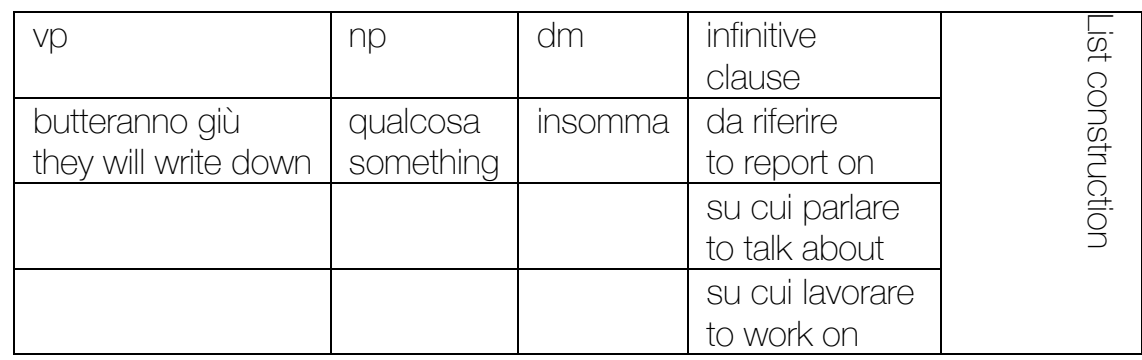

The LCs present a series of elements either as examples of a set or as specific cases that help the addressee to understand the discourse, as in (22), leaving the boundaries of the set undetermined (Jefferson 1990). The same happens with the CxsNuSeries, which transmit an even more indefinite meaning than that transmitted by the numeral pairs because they do not indicate the limits of the quantitative interval to which they refer. It may then happen that even if small numerals are used, the approximate quantity indicated corresponds to a multal quantifier, as in the following example, taken from a newspaper article:

(22) II fatto è che questi sceneggiati, in due tre quattro puntate, mi si confondono in testa (la Repubblica)

'The fact is that these TV series, in two three or four (lit. two three four) episodes confuse me'

Although these constructions can also be in the form of closed lists with a close marker, such as etcetera and so on, I have not found any examples of this kind, as it happens, in Italian spoken corpora also for most of the LCs (Voghera 2018).

\subsection{Constructions with single numerals}

The most interesting approximate constructions with cardinal numerals is undoubtedly the one with single numerals (CxNuS); these constructions are possible both with small and large mumerals, even if, we will see, there are differences between them.

(23) avrà detto due parole / <a alta voce / in classe' (C-ORAL ROM)

'(s/he)will have said a couple of words (lit. two words) aloud in class'

(24) il giallo / del ritrovamento di queste \&fe [/] di queste teste / attraverso / \&he / mille indizi / che erano stati trascurati (C-ORAL ROM)

'the mistery of the finding of these \&fe of these heads thanks to /he /thousands of clues that had not been taken into consideration'

(25) digo para nada para dos minutos (C-ORAL ROM) 'I say for nothing for two minutes'traduco io'

(26) para arriba / para abajo y [/ y / es que / hay cien mil cosas que ver (C-ORAL ROM) 'everywhere there are hundreds of things to see'

Unlike previous constructions, the above ones have restrictions both in the type of numerals and in the nouns that can appear in them. In the CxsNuS, both small and large round numbers are mainly used (Pollon, Jansen 1996). Both languages mainly use the numerals two, four, five and ten, but while in Italian the frequencies are distributed almost 
equally, with a slight prevalence for five, in Spanish two covers almost half of the uses (Voghera 2017a). Unlike small numerals, large numerals allow for more creativity, although it is difficult to document their usage in the corpora. It is therefore possible to replace a large numeral with almost any other without changing the meaning of the construction:

(27) como siempre / hay trescientas mil/ excepciones (C-ORAL ROM) 'as usual there are three hundred thousand exceptions'

(28) oh! / yo tengo> ocho mil veces / condiciones < veritativas> (C-ORAL ROM) ' oh! I have eight thousand truthful conditions'

With small numerals the nouns that occur most frequently are those of time portions: minutes, seconds, days, weeks, while there seem to be no recurring choices in the case of constructions with large numerals. The lexical choice also decides whether the reading should be approximate or not. Unless we are in a particular context, the sentence (29a.) makes us opt towards an approximate reading, while the sentence (29b.) makes us opt towards a cardinal interpretation

(29) a. Ci vediamo tra due minuti 'See you in two minutes'

b. Ci vediamo tra due ore 'See you in two hours'

There are of course ambiguous cases, such as (30), in which, out of context and without intonation, it is difficult to say whether it is an approximation or not:

(30) Ti vanno le polpette?

'Would you like the meatballs?

Sì, dammene due

'Yes, please give me two'

The match between the numeral and the approximate quantity can also derive from idiomatic factors not related to granularity. As we know, the choice of the numerals is strongly connected to historical and cultural factors, as always happens in languages (Lavric 2010, Garcea and Bazzanella 2011, Bazzanella 2011). For example, the sentence (31)b has an approximate reading, while the sentence (31)a no, not because the numeral is inadequate for the purpose (Dehaene \& Mehler 1992): we will see in the next paragraph that numeral four is very frequent in idiomatic constructions.

(31) a. Ci vediamo tra quattro minuti 'See you in four minutes'

b. Ci vediamo tra cinque minuti 'See you in five minute'

The approximate interpretation is cancelled, or at least weakened, when in the construction there is a determinant of the $\mathrm{N}$ :

(32) Sono stati $\mathrm{i}_{\mathrm{DET}}[\text { due minuti }]_{\mathrm{SN}}$ più terribili della vostra vita [...] (la Repubblica)

'They were the worst two minutes of your life[...]'

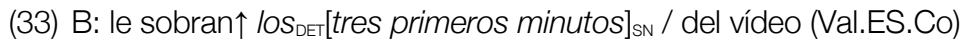

' the first three minutes execeed/ of the video'

For most speakers, even the mere presence of a noun modifier, which increases the meaning intension of the noun, has the effect of reducing or even cancelling the possibility of an approximate interpretation: 
(34) En [cinco increíbles minutos $]_{S N}$ en la segunda parte el Tottenham fulminó el partido (www.elespectador.com)

'In five incredible minutes in the second half Tottenham won the match'

With large numerals the presence of a modifier does not cancel the approximate interpretation (35), and the presence of the article makes the construction ambiguous, but does not completely exclude the approximate interpretation (36):

(35) para arriba/ para abajo y [/] y / es que / hay cien mil cosas interesantes que ver (C-ORAL $\mathrm{ROM})$

'everywhere and there are thousands of things to see'

(36) le cento persone più influenti al mondo (www.panorama.it) 'the hundred most influential people of the world'

The different behaviour of small and large numerals in the case of the presence of a determinant or a modifier depends on the fact, as we will see in the last paragraph, that the approximate use of large numerals implies always a shift into an exaggerating reactive frame (McCarthy, Carter 2004). This means that the approximate hyperbolic reading is always possible, unless in specific contexts.

\section{4. The idiomatic numeral constructions $\mathrm{CxIdiomNu}$}

There are some numeral constructions that are proper idioms, i.e. expressions whose meaning is non-compositional and non-transparent (De Mauro\&Voghera 1996). Noncompositionality indicates that the meaning of the construction is not entirely understandable from the sum of the meanings of the component elements, examples in (37), while non-transparency indicates that the literal meaning of the expression has no relation with the meaning of the construction, examples in (38):

(37) scuola elementare, lista negra

'elementary school', 'black list'

(38) luna di miele, quedarse a la luna de Valencia

'honeymoon', 'to be disappointed'

The meaning of the expressions in (37) cannot be calculated from the sum of the meanings of the words that compose them, although their meaning is the same as that of the syntactic heads. For this reason, they maintain a certain semantic transparency. On the contrary, the meaning of the idioms in (38) is not hyponym of their syntactic heads and is not retraceable by metaphor or metonymy.

Although we observe a shift from the literal meaning to a wider figurative meaning, the idiomatic numeral constructions (CxIdiomNu) are neither completely non-compositional nor opaque ${ }^{5}$. Most of them are specified with small numerals, while those with large numerals seem rather limited. I show some examples: valere due lire (lit. to be worth two liras) 'not be worth a sausage', decir dos palabras 'say two words', essere quattro

5 In this section, I consider only CxldiomNu that have a quantitative approximate meaning; for idioms with numerals and numbers in Italian and Spanish, see Lavric 2010 and Bazzanella 2011. 
gatti/ ser cuatro gatos (lit. to be four cats ) 'be few peoples', fare due/quattro passi (lit. to make two/four steps) 'to work for a short time', cien por cien 'hundred per cent', pregunta de millon 'the million dollar question'.

Some of these constructions have lost the value of quantitative approximation to acquire rather a meaning that expresses the quality of an event. Fare due passi (lit. 'make two steps') means only secondarily 'to walk for a short time', it rather means 'leisurely walk, as dire due parole (lit. 'say two words') does not mean 'talk for a short time' , but ' say a little word with you', which implies a sort of a confidential relationship between the participants. Thus, these constructions no longer express a quantitative evaluation of the duration of the event, but the attitude of the actors involved in the activity ${ }^{\text {. Even }}$ expressions with large numerals communicate, in the opposite way, the emphasis that the speaker wants to give to his statement:

(39) el <|cien|> por cien / a nadie se lo / pagaban en [/] en dólares //(C-ORAL ROM)

'one hundred per cent nobody was paid in dollars'

In (39) cien por cien works as an intensifier of the utterance and then it operates on the illocutive force of the statement, increasing its assertiveness.

The use of formatives, words, constructions, originally dedicated to the expression of quantitative values to express qualitative evaluations is well known. It happens, for example, with degree words or diminutive and augmentative affixes in languages such as in Italian and Spanish in intensification and attenuation processes (Bolinger 1972; Labov 1984; Caffi 2007; Ghezzi 2013; Albelda 2014; Grandi\&Körtvélyessy (eds.) 2015; Voghera 2017c). Similarly, CxIdiomNu are used to modulate the degree of speaker's involvement, commitment and the illocutive force. The shift towards meanings that imply the subjective expression of speaker's attitude was already noted in most grammaticalisation clines and in the process of agglutination and opacification of the idioms (Traugott 1982, 2010).

Since the change from quantitative approximation to qualitative evaluation and then expression of a personal attitude is only the possible exit of a gradual process, not all the CxIdiomNu necessarily reach this stage. For example, essere quattro gatti (lit. 'to be four cats') 'to be a few people' still maintains a meaning of quantitative approximation, while including in its meaning a negative evaluation by the speaker.

\section{Constructional and functional continua}

The analysis of the contexts of the approximate uses of numerals shows that the approximate value is determined by an interpenetration of construction patterns and lexicon. The approximate values of the numerals are realized in four types of construction that are distinguished by the progressive increase of the lexical and syntactic restrictions

\footnotetext{
${ }^{6}$ The loss of the temporal duration in the meaning of some of these idioms is registered in the Spanish translation in Grande Dizionario Hoepli by Laura Tam: fare due chiacchiere 'charlar', fare due passi 'dar una vuelta.
} 
imposed on the component elements and, consequently, by the degree of distance from the cardinal meaning of the numerals.

The CxNuPair is a productive construction not specified at the lexical level, i.e. it does not require specific lexemes, since any pair of numerals and nominal head can be used, even if the due o tre/dos o tres ('two or three') pair is by far the most widely used in both Italian and Spanish. Its meaning is globally approximate, but from the formal point of view it is still possible to go back to the formative process of construction. Also the CxNuSeries, in which we can have more numbers that follow each other, is productive and not specified lexically. The 'open list' pattern produces approximate and indefinite meanings, which become paucal or multal in relation to the quantified elements. The CxNuS, in which only one numeral is used, is a semi-specified construction at the lexical level because it has lexical restrictions, especially for small numerals. It is, for example, possible to use numeral quattro ('four') to express a small amount of cose ('objects'), but not of minuti ('minutes'). These restrictions do not appear with large numerals. Also, the frequency of nominal heads designating time intervals is more marked with small numbers, to the point that expressions such as tra due/cinque/dieci minuti('in two/five/ten minutes') no longer mean 'in a few minutes', but 'soon'. This means that although the construction is not specified at lexical level, there are highly preferred lexemes. This does not happen so clearly with large numerals. The approximate meaning is cancelled or reduced when the numeral is preceded by a determinant or the nominal head is modified. Finally, there is the CxldiomNU, an approximate idiomatic numeral construction, fully specified at the lexical level, which can express vague quantification, but in some cases also the attitude of the speaker, his/her relationship with what s/he is saying and with the interlocutor.

As a matter of fact, all constructions can express values that go beyond quantitative approximation. We know that vagueness on the propositional level can actually perform functions on other levels: modulation of illocutive force, level of involvement and commitment to our words and so on. There is a substantial agreement among scholars that there is a continuous shift of functions between the most strictly semantic level and the pragmatic level. The Val.Es.Co. group calls these move from atenuación/intensificación en lo dicho to atenuación/intensificación en el decir to atenuación/ intensificación pragmática (Briz 1995, 2003; Albelda\&Mancera 2011). Caffi (2007) distinguishes among bushes, which operate on the propositional content, hedges, which operate mainly on the illocutive force, and shields, which operate mainly on the deictic origin of the enunciation and therefore modulate the closeness or distance between the speaker and the text. Voghera $(2012,2017 b)$ proposes to call informative vagueness the one that has its scope on the propositional content and relational vagueness the one that puts into play the relationship between speakers and speech or between speaker and recipient?.

These passages from propositional domain to subjective and intersubjective domains manifest in the fact that constructions with both small and large numerals can be used as strategies of politeness, to make the communicative exchange more fluid, inclusive and socially appropriate. Constructions with small numbers can be used as a negative

7 There is a third type of vagueness, the discursive vagueness, which depends on online processing and programming factors, which is not specifically relevant for the present topic (Voghera 2017b, Voghera\&Borges 2017). 
courtesy strategy (Brown and Levinson 1987), which tends to respect the personal space of the addressee with indirect requests, to reduce the imposition of an offer or any other attitude of the hearer. Constructions typically associated with negative courtesy are indirect linguistic acts, hedges (I believe, I think, let's say, as far as I know...) and expressions that can minimize the involvement and commitment of speakers (Brown and Levinson 1987, Caffi 2007). In the following example, the use of due minuti ('two minutes') can indicates, on the one hand, that the speaker needs a short meeting, but, on the other hand, that it is a meeting to which s/he does not want to give too much importance, an informal meeting. This does not overburden the person receiving the request, but also protects the person making the request from a rejection.

hai due minuti?

$$
\text { Lit. 'Have you got two minutes?' }
$$

On the contrary, constructions with large numbers, which tend towards hyperbole and emphasis, express a great involvement of the speaker in what s/he says, and are often used in positive politeness (Brown and Levinson 1987). Exaggeration and intensification are some of the strategies put in place because they allow the speaker to highlight and maximize the appreciation and understanding of the addressee. In these cases, the speaker has an inclusive approach to the listener and assumes that the s/he shares his or her basic desires and beliefs. In the use of a large number is a way to communicate the emotive participation of speaker participate to the state of mind and the efforts of the person s/he is speaking about:

(38) <pobrecillo> // también el pobre / os hace mil <planes hhh> //(C-ORAL ROM) 'poor thing the poor man also makes you thousands of plans hhh'

Summing up, two general considerations can derived from all the considered data. Firstly, it is possible to trace a continuum of NuCxs based on their degree of cohesion, fixedness, specificity and idiomaticity, which correlates with the kind of approximate or vague meaning and function. The more the NuCxs become idiomatic the less they express quantity. In many cases, the constructions acquire a pragmatic value and codify a manner of express the degree of commitment, the attitude of the speakers and the kind of relationship s/he would like to enter into with the addressee. In these cases, the various levels of vagueness are often thickly intertwined and not easily untangled. Secondly, the approximate numeral constructions with small numerals seem more specified and fixed compared with those with large ones. Probably this is due to their frequency, since we know that small numerals are much more used than large numerals (Mehler\&Dehaene 1992). Although it is necessary to do further research on this specific point, these results seem to be another element confirming that the means to be vague are more numerous than those that convey the opposite functions (Caffi 2007).

\section{References}

Albelda Marco, Marta (2014): «Escalaridad y evaluación: rasgos caracterizadores de la intensificación pragmática», en Putska, Elissa/Goldschmitt, Stefanie, eds., Emotionen, Expressivität, Emphase, Berlín: Erich Schmidt Verlag, 79-94.
Albelda Marco, Marta, Mancera Cestero Ana María (2011): «De nuevo, sobre los procedimientos de atenuación lingüística», Español actual: Revista de español vivo 96: 9-40. 
Brown, Penelope, and Steven C. Levinson (1987): Politeness: Some Universals in Language Use, Cambridge: Cambridge University Press.

Channell, Joanna (1994): Vague Language, Oxford: Oxford University Press.

Crystal, David, Davy, Derek (1975): Advanced conversational English, London: Longman Publishing Group.

Cutting, Joan. (2007) ed.: Vague Language Explored, Palgrave Macmillan: Basingstoke.

Jucker, Andreas H. et alii (2003): «Interactive aspects of vagueness in conversation», Journal of Pragmatics, 35, 1737- 1769.

Bolinger, Dwight (1972): Degree Words, Berlin: De Gruyter

Bazzanella,Carla (2011): Numeri per parlare. Da 'quattro chiacchiere'a 'grazie mille', in collaboration with Rosa Pugliese, Erling Strudsholm, Roma/Bari: Laterza.

Bertuccelli Papi, Marcella (2011): «ll linguaggio della cortesia» L'enciclopedia dell'italiano Treccani.

Briz, Antonio (1998): El español coloquial en la conversación. Esbozo de pragmagramática, Barcelona, Ariel.

Briz, Antonio (2003): La estrategia atenuadora en la conversación cotidiana española. Actas del Primer Coloquio del Programa Edice. La perspectiva no etnocentrista de la cortesía: identidad sociocultural de las comunidades hispanohablantes, 17-46.

Caffi, Claudia (2007): Mitigation, Amsterdam, Elsevier.

Channell, Joanna (1994): Vague language. Oxford: Oxford University Press.

Cresti Emanuela, Moneglia Massimo (2005) eds.: C-ORAL-ROM Integrated Reference Corpora for Spoken Romance Languages, Amsterdam, Benjamins.

De Mauro, Tullio (1982): Minisemantica dei linguaggi non verbali e delle lingue, RomaBari: Laterza.

De Mauro, Tullio, Voghera, Miriam (1996): «Scala mobile. Un punto di vista sui lessemi complessi», in Benincà, P., Guglielmo Cinque, Tullio De Mauro, Nigel Vincent, (eds.), Italiano e dialetti nel tempo, Roma: Bulzoni, 99-131.

Dehaene, Stanislas (1997): The Number Sense: How the Mind Creates Mathematics, Oxford: Oxford University Press.

Dehaene, Stanislas, Mehler, Jacques (1992): "Cross-linguistic regularities in the frequency of number words», Cognition, 43.1, 1-29.

Devos, Filip, Maesfranckx, Patricia, De Tré, Guy (1998): "Granularity in the interpretation of around in approximative lexical time indications», Journal of Quantitative Linguistics, 5.3, 167-173.

Eriksson, Kimmo; Bayley, Drew H.; Geary, David C. (2010): "The grammar of approximating number pairs», Memory \& cognition, 38.3, 333-343.

Garcea, Alessandro, Bazzanella, Carla (2011): «Tria verbi. Numeri e approssimazione in latino», in Balbo,A., Federica Bessone, Ermanno Malaspina (eds.), Tanti affetti in tal momento, Edizioni dell'Orso: Alessandria, 437-449.

Ghezzi, Chiara (2013): Vagueness Markers in Contemporary Italian: Intergenerational Variation and pragmatic Change, Tesi di dottorato, Università di Pavia.

Grandi, Nicola, Körtvélyessy, Lívia ed. (2015): Edinburgh handbook of evaluative morphology.

Halberda, Justin; Feigenson, Lisa, 2008, "Developmental change in the acuity of the" Number Sense": The Approximate Number System in 3-, 4-, 5-, and 6-year-olds and adults». Developmental psychology, 44.5, 1457- 1465.

lacobini, Claudio Aurelio De Rosa, Giovanna Schirato (2017): "Criteri e strategie di classificazione morfo-sintattica dei testi del corpus MIDIA» in D'Achille, Paolo, Grossmann, Maria a cura di, Per la storia della formazione delle parole in italiano, Firenze: Cesati, 33-52.

Jansen, Carel Pollmann, JM., Mathijs M.W. (2001): «On round numbers: Pragmatic aspects of numerical expressions» Journal of Quantitative Linguistics, 8.3, 187-201.

Jefferson, Gail (1990): «List construction as a task and interactional resource», in Psathas, G. M. (ed.), Interactional Competence. Lanham M.D.: University Press of America, 63-93.

Krifka, Manfred (2007): «Approximate interpretation of number words: A case for strategic communication». Cognitive foundations of interpretation, 111-126.

Labov, William (1984): Intensity, in Schiffrin, D. (ed.), Meaning, form, and use in context: Linguistic applications, Georgetown Round Table on Language and Linguistics, Washington, Georgetown University Press, 43-70.

Lavric, Eva (2010): «Hyperbolic approximative numerals in cross-cultural comparison», in Kaltenböck, Gunther, Wiltrud Mihatsch, Stefan Schneider (eds.), New Approaches to Hedging. Bingley: Emerald Group Publishing Limited, 123-164

Masini, Francesca (2016): La grammatica delle costruzioni, Roma, Carocci. 
Mihatsch, Wiltrud (2010a): «The diachrony of rounders and adaptors: Approximation and unidirectional change», in Kaltenböck, Gunther, Wiltrud Mihatsch, Stefan Schneider (eds.), New Approaches to Hedging, Bingley: Emerald Group Publishing Limited, 9-93.

Mihatsch, Wiltrud (2010b): "Wird man von hustensaft wie so ne art bekifft? Approximations marker in romanischen Sprache, Frankfurt am Main: Analecticia Romanica Band 75. Vittorio Klostermann.

Park, Joonkoo, Brannon, Elizabeth M. (2013): «Training the approximate number system improves math proficiency», Psychological science, 24.10: 2013-2019.

Pica, Pierre, Lemer, Cathy, Dehaene, Stanislas, Izard, Veronique (2004): «Exact and Approximative Arithmetic in an Amazonian Indigene Group». Science, American Association for the Advancement of Science, 306 (5695), 499-50.

Traugott, Elisabeth C. (1982): «From propositional to textual and expressive meanings: Some semantic- pragmatic aspects of grammaticalization», in Lehman, Wilfred, Yakov Malkiel (eds.), Perspectives on historical linguistics, 245-271.

Traugott, Elisabeth C. (2010): «(Inter)subjectivity and (inter)subjectification: A reassessment», in Kristin Davidse, Lieven Vandelanotte, Hubert Cuyckens (eds.), Subjectification, Intersubjectification and Grammaticalization. Berlin/Boston, De Gruyter Mouton, 29-71.

Voghera, Miriam (2012): Chitarre, violino, banjo e cose del genere, in Thornton, Anna M., Miriam Voghera (eds.), Per Tullio De Mauro. Studi offerti dalle allieve in occasione del suo $80^{\circ}$ compleanno, Roma: Aracne, 341-364.

Voghera, Miriam (2017a): «Costruzioni di piccoli numeri: la vaghezza intenzionale in funzione», in Oana-Dana Balaş Adriana Ciama Mihai Enăchescu Anamaria Gebăilă Roxana Voicu (eds.) (a cura di), L'expression de l'imprécision dans les langues romanes

Voghera, Miriam (2017b): Dal parlato alla grammatica, Roma, Carocci,.

Voghera, Miriam (2017c): «Quando vaghezza e focus entrano in contatto: il caso di un attimo, anzi un attimino»,,in D'Alessandro, Roberta, Gabriele lannàccaro, Diana Passino, Anna M. Thornton (eds.), Di tutti i colori. Studi linguistici per Maria Grossmann Utrecht University, 385-397.

Voghera, Miriam, Borges, Carla (2017): "Vagueness expressions in Italian, Spanish and English task-oriented dialogues " Normas, Vol. 7, 57-74. doi: http://dx.doi.org/10.7203/Normas.7.10424
Voghera, Miriam, lacobini, Claudio, Savy, Renata Cutugno, Francesco, De Rosa, Aurelio, Alfano, lolanda (2014): "VoLIP: a searchable Italian spoken corpus, in Complex Visibles Out There». In Ludmila Veselovská, Markéta Janebová (eds.), Language Use and Linguistic Structure, Proceedings of the Olomouc Linguistics Colloquium, Palacký University, Olomouc, 627-640. 